\title{
THE PROTECTIVE ROLE OF SESAME SEED OIL AGAINST PENCONAZOLE-INDUCED OXIDATIVE STRESS IN THE TESTES OF MALE RATS
}

\author{
BORAI, IBRAHIM H. ${ }^{1}$, AZZA A. ATEF ${ }^{1}$, AFAF A. EL KASHOURY ${ }^{2}$, \\ M. M. SAID ${ }^{1}$ and RANIA A. MOHAMED ${ }^{2, *}$ \\ 1. Biochemistry Department, Faculty of Science, Ain Shams University, Cairo, Egypt \\ 2. Central Agricultural Pesticides Laboratory (CAPL), ARC, Giza, Egypt \\ *To whom correspondence should be addressed Rania A Mohamed
}

(Manuscript received 6 August 2017)

\begin{abstract}
$\mathrm{T}$ he present study was carried out to elucidate the potential protective effect of sesame seed oil (Ses) against testicular oxidative stress induced by penconazole fungicide in adult male albino rats. Sixty male rats were divided into six groups, a control group, Ses-supplemented rats, rats treated with penconazole at two doses $30 \& 60 \mathrm{mg} / \mathrm{kg}$ body weight, which represent $1 / 20$ and $1 / 10 L D_{50}$ respectively, rats co-administered Ses along with penconazole treatment. Testicular redox status was evaluated, including lipid peroxidation (LPO) level, reduced glutathione (GSH) level, catalase (CAT) and superoxide dismutase (SOD) activities and the residues of penconazole in testicular tissue was determined. Penconazole induced oxidative stress in testicular tissue as demonstrated by the significant increase in the lipid peroxidation level as well as the significant reduction in antioxidant activity. In contrast, co-administration of Ses along with penconazole treatment counteracted the induced oxidative stress by lowering lipid peroxidation level and enhancing testicular antioxidant enzymes activities. In addition, residues of penconazole in the testes of treated rats were below the determination limit. In conclusion, supplementation of male rats with sesame seed oil protects the testes against penconazole-induced oxidative stress which could be attributed to the antioxidant property of the sesame seed oil.
\end{abstract}

Keywords: Oxidative stress, penconazole, sesame seed oil, testes

\section{INTRODUCTION}

Pesticides have been widely used allover the world and they have a significant impact on the economy, the environment and public health. They enable the development of agriculture and farming production by controlling a wide range of pestes and disease (Aiche et al., 2015).

Pesticides may have adverse health effects for human beings. The main adverse health effects are reproductive effects, effects on the immune system, disrupting the hormonal balance and causing cancer. They may cause reproductive toxicity through several different mechanisms, including direct damage to the structure of cells, interference with biochemical processes necessary for normal cell 
function, and biotransformation resulting in toxic metabolites. The manifestation of these effects depends on the type of pesticide and on level and duration of exposure (Mnif et al., 2011).

Triazole fungicides, a large family of broad-spectrum fungicides, are one of the current-use pesticides in the world. The widespread use of these fungicides has raised serious concerns over their potential hazards to environmental safety and human health. They have brought a severe pollution in surface water, soil, and food. In a series of toxicological studies, some fungicides belonging to the triazole class have been observed to be hepatotoxic, tumorigenic, teratogenic, endocrine disrupting, and testicular dysfunction (Chaâbane et al., 2017ª).

Penconazole, a systemic triazole, is one of the commonly used triazole fungicides in many countries throughout the world, which has a curative and preventive efficacy against powdery mildew. Penconazole, with a mean half-life value of 117 days, is recognized to be recalcitrant to degradation and susceptible to accumulate in soils (Singh, 2005). Moreover, it has been found in excess as residues in several agricultural products. Because of its occurrence in the environment and the possible exposure of the general population to contaminated food stuffs, penconazole may represent a risk factor for human health (Cabizza et al., 2012). Previous studies had shown that penconazole is a potent inducer of oxidative stress in hepatic, cardiac, brain and nephritic tissues of adult rats (Chaâbane et al., 2015; Chaâbane et al., 2016; Chaâbane et al., 2017a\&b).

There is an increasing interest in discovering the protective biological function of natural compounds contained in dietary plants due to their antioxidative properties and their possible roles in intra and extracellular defense against oxygen radicals and lipid peroxides in response to oxidative stress (Marzook et al., 2014).

Sesame seed oil is derived from seed of Sesamum indicum L., a herbaceous annual plant in the Pedaliaceae family. It is rich in fatty acids and various bioactive compounds. It is rich in vitamins $A, B, C$ and $E$ as well as iron, calcium, magnesium, zinc and copper. Also, sesame seed oil extract contains a highe total phenolic content (TPC) compared to other commonly available vegetable oils (Isha and Milind, 2012).

The present study was conducted to elucidate, for the first time, the impact of penconazole fungicide on redox status in the testicular tissue of adult male rats as well as the protective effect of sesame seed oil against penconazole- induced toxicity. 


\section{MATERIALS AND METHODS}

\section{Experimental animals}

In the present study, adult male Wistar rats were purchased from the breeding unit of Egyptian Stock Holding Company for Biological Products, Vaccines, Sera, and Drugs (Cairo). The animals were housed in plastic cages (5/cage) and had a free access to commercial pellet diet and tap water for one week before the start of the experiment as an acclimatization period.

\section{Chemicals}

Penconazole fungicide (PEN), commercially known as Topas, a $10 \%$ emulsifiable concentrate formulation (EC), was obtained from Syngenta Company (Egypt). The oral median lethal dose $\left(L_{50}\right)$ of penconazole (administrated orally to rats) was found to be $620.71 \mathrm{mg} / \mathrm{kg}$ b. w. (Weil, 1952). Sesame seed oil (Ses), derived from the seeds of Sesamum indicum $L$., was purchased from a local market (Haraz shop, Egypt).

\section{Experimental design}

A total of 60 adult male Wistar rats, initially weighing ( $170 \pm 15 \mathrm{~g})$, was equally allocated into six groups as follows: group 1 (Control); rats remained intact as a normal control group, group 2 (Ses); rats received sesame seed oil per os at a dose of $1 \mathrm{ml} / \mathrm{kg} \mathrm{b.} \mathrm{w.} \mathrm{(5} \mathrm{days/week)} \mathrm{for} 90$ days (Hsu et al., 2010), group 3, (low dose of penconazole (LD PEN)); rats were treated with penconazole at a dose of $30 \mathrm{mg} / \mathrm{kg} \mathrm{b}$. w. (representing $1 / 20$ LD50, 5 days per week) for 90 days, group 4 (high dose of penconazole (HD PEN)); rats were treated with penconazole at a dose of $60 \mathrm{mg} / \mathrm{kg} \mathrm{b}$. w. (representing $1 / 10$ LD50, 5 days per week) for 90 days, group 5 (Ses+LD PEN); rats were treated with sesame seed oil at a dose of $1 \mathrm{ml} / \mathrm{kg} \mathrm{b}$. w. ( 5 days/week) for $2 \mathrm{hrs}$. prior to the oral administration of penconazole (30 mg/kg b. w.) (5 days/week) for 90 days, group 6 (Ses+HD PEN); rats were treated with sesame seed oil at a dose of 1 $\mathrm{ml} / \mathrm{kg} \mathrm{b.} \mathrm{w.} \mathrm{(5} \mathrm{days/week)} 2$ hrs. prior to the oral administration of penconazole (60 $\mathrm{mg} / \mathrm{kg}$ b. w.) (5 days/week) for 90 days. During the experimental period, the animals were examined for any observable signs of abnormalities and death and were weighed weekly.

At the end of experimental period (90 days), rats were weighed then sacrificed and testes were immediately removed at autopsy, cleaned of adhering tissues and washed in ice cold isotonic saline then dried with a piece of filter paper, weighed and frozen in liquid nitrogen and kept at $-40^{\circ} \mathrm{C}$ until homogenization. 


\section{Preparation of testicular tissue homogenate}

A $10 \%$ testicular homogenate was prepared in ice cold potassium chloride $(1.17 \% \mathrm{KCl})$ using a chilled glass-teflon Potter-Elvehjem tissue homogenizer. An aliquot of whole testicular tissue homogenate was used for the estimation of lipid peroxidation (MDA) and reduced glutathione (GSH). The remaining tissue homogenate was centrifuged at $10,000 \mathrm{xg}$ for $20 \mathrm{~min}$ at $4^{\circ} \mathrm{C}$ and the supernatant was used for the estimation of catalase (CAT) and superoxide dismutase (SOD).

\section{Biochemical analysis}

\section{Determination of testicular malondialdehyde level}

Lipid peroxidation (LPO) level in testicular homogenates was evaluated according to the colorimetric method of Wills (1966), where lipid peroxides concentration was determined by analyzing the thiobarbituric acid reactive substances as malondialdehyde (MDA), and the extent of lipid peroxidation was expressed as $\mathrm{nmol} \mathrm{MDA} / \mathrm{g}$ tissue.

\section{Determination of testicular reduced glutathione level}

Testicular reduced glutathione (GSH) level was measured according to the colorimetric method of Ellman (1959) that depends on the reaction between reduced glutathione and Ellman's reagent [5,5-dithiobis-(2-nitrobenzoic acid)] to form a stable yellow color of 5-thio-2-nitrobenzoic acid, which was measured colorimetrically at 412 nm.

\section{Determination of testicular catalase activity}

Testicular catalase (CAT) activity was estimated according to the kinetic method of Cohen et al. (1970), which depends on the decomposition of hydrogen peroxide catalyzed by catalase into water and molecular oxygen that is proportion to the concentration of catalase in the sample. The catalase activity was expressed as $\mathrm{U} / \mathrm{mg}$ protein.

\section{Determination of testicular superoxide dismutase activity}

Testicular superoxide dismutase (SOD) activity was assessed in testicular homogenate by the kinetic method of Marklund and Marklund (1974) that depends on spontaneous auto-oxidation of pyrogallol in aqueous solution to produce superoxide anion radicals. The presence of superoxide dismutase (SOD) in the reaction medium scavenges the superoxide anion radical, which further decreases the overall rate of pyrogallol auto-oxidation. The SOD activity was expressed as $\mathrm{U} / \mathrm{mg}$ protein.

\section{Protein estimation}

Total protein content in testicular tissue homogenates was estimated by the dye binding method of Bradford (1976). 


\section{Determination of penconazole residues in testes}

The determination of penconazole residues in the testes was performed using gas chromatography (GC), Agilent GC 6890 SN occupied by Electrone Capture Detector (ECD). The technique mentioned by Pang et al. (2006) was followed to extract penconazole residues from rat testes.

\section{Recovery Study}

The analytical method was examined by spiking known tissue samples with a known amount of penconazole reference standard, then these fortified samples were subjected to perform the entire procedures previously mentioned. The recovery rate of penconazole was performed at two levels $(0.5 \& 1 \mathrm{ppm})$, where the limit of determination (LOD) of penconazole was $0.001 \mathrm{ppm}$.

\section{Recovery rate of penconazole.}

\begin{tabular}{|c|c|}
\hline $\begin{array}{c}\text { Penconazole fortification } \\
\text { level (ppm) }\end{array}$ & Testes \\
\hline $\mathbf{0 . 5}$ & $96.21 \%$ \\
\hline $\mathbf{1}$ & $81.77 \%$ \\
\hline
\end{tabular}

\section{Statistical Analysis}

The data were statistically evaluated as mean values for each group and its corresponding standard deviation (SD). Statistical analysis of differences between means was carried out using one-way analysis of variance (ANOVA). In case of a significant F-ratio, posthoc Least Significant Difference (LSD) test for multiple comparisons was used to evaluate the statistical significance between groups at $\mathrm{P}<0.05$ level of significance (Turner and Thayer, 2001).

\section{RESULTS AND DISCUSSION}

Effect of penconazole and sesame seed oil alone or co-administered with penconazole on body weight and absolute testes weight in male rats.

There were no significant differences in the body weight and testes weights in all treated groups, compared to the normal control group.

Effect of penconazole and sesame seed oil alone or co-administered with penconazole on testicular lipid peroxidation in male rats.

Rats treated with penconazole exhibited a significant increase in lipid peroxidation in testicular tissue, compared to control. However, co-administration of sesame seed oil along with penconazole treatment significantly decreased lipid peroxidation, compared to normal control (Table 1 and Figure 1). 


\section{Effect of penconazole and sesame seed oil alone or co-administered with penconazole on testicular GSH level in male rats.}

Reduced glutathione levels did not change significantly in all treated groups, compared to the control group (Table 1 and Figure 2).

\section{Effect of penconazole and sesame seed oil alone or co-administered with} penconazole on testicular enzymatic antioxidant status in male rats.

Treatment with low and high doses of penconazole significantly reduced CAT and SOD activities, compared to the normal control group. Moreover, co-administration of sesame seed oil along with penconazole treatment normalized CAT activity in both penconazole groups, and significantly reduced SOD activity, compared to penconazole-treated rats (Table 1 and Figures 3\&4).

\section{Determination of penconazole residues in testicular tissue}

Penconazole residues were below the limit of determination $(0.001 \mathrm{ppm})$ in testicular tissues.

In recent years, there is a growing concern worldwide over the indiscriminate use of pesticides, resulting in environmental pollution and toxicity risk to non-target organisms. Nowadays, the extensive use of triazole pesticides derivatives in agriculture to reduced powdery mildew in different crops. penconazole, a triazole fungicide, become a pesticide of choice in many countries throughout the world due to its high potency to reduced this fungus in crops (Chaâbane et al., 2017ª). The present study carried out to evaluate the potential testicular toxicity of penconazole in adult male rats and to investigate the possible protective effect of sesame seed oil.

In toxicological studies, body and/or organ weights are the important criteria for the evaluation of toxicity. In the current study, no significant changes were observed in the final body weight as well as testicular weights in all treated groups, compared to the controls. Our results agree with that of Chaâbane et al., 2015 and Chaâbane et al., 2017a\&b who documented that treatment rats with penconazole had no effect on body weight. They suggest that penconazole did not probably affect the appetite of rats.

There is evidence that many chemical agents, pesticides, xenobiotics, environmental pollutants and drugs are toxic to cells, which may be due to a simultaneously increased oxidative stress and decreased endogenous oxidative defense potential (El-Kashoury et al., 2010), and exposure of experimental animals to pesticides is known to induce lipid peroxidation in various tissues, which leads to adverse biological effects (El-Demerdash et al. 2004).

Mammalian testis cell membranes are rich in polyunsaturated fatty acids (PUFA) and are sensitive to oxygen and nitrogen derived free radicals. Increased 
generation of ROS subjects the cell to oxidative stress that damages cellular DNA, proteins, and lipids which leads to cell death (Najafi et al., 2010). The testis has antioxidant systems comprising both enzymes and free radical scavengers. Usually, there is a balance between concentrations of reactive oxygen species (ROS) and antioxidant scavenging systems that enable normal sperm production (Silberstein et al., 2016).

In the present study, lipid peroxidation (LPO) level is used as an index of oxidative stress. Our results indicated that oral administration of penconazole caused oxidative stress in the testes of rats, as demonstrated by the enhancement of LPO, along with the suppression of catalase (CAT) and superoxide dismutase (SOD) activities, compared to the control groups.

Penconazole is the most lipophilic triazole fungicide. Therefore, it is supposed that this fungicide may bind extensively to testicular membrane and cause damage by inducing lipid peroxidation. Moreover, the increased MDA level observed in testicular tissue of animals exposed to penconazole could be probably ascribed to the excessive production of ROS caused by this fungicide leading to testicular injury (Chaâbane et al., 2017b).

Superoxide dismutase is considered the first line of defense against deleterious effect of oxyradical in the cell. It catalyzes the conversion of superoxide radical $\left(\mathrm{O}_{2}^{-}\right)$to hydrogen peroxide $\left(\mathrm{H}_{2} \mathrm{O}_{2}\right)$, while catalase (CAT) converts $\mathrm{H}_{2} \mathrm{O}_{2}$ to $\mathrm{H}_{2} \mathrm{O}$. Therefore, these enzymatic antioxidants may counteract oxidative stress and can alleviate the toxic effects of reactive oxygen species (El-Kashoury and Tag El-Din, 2010).

The reduction in the activity of CAT may be due to a direct inactivation caused by excess ROS production in mitochondria and microsomes of penconazole-treated rats (Latchoumycandane and Mathur, 2002). Also, SOD protects the catalase against inhibition by the superoxide anion. Suppression of SOD following penconazole treatment makes the testes unable to get rid of superoxide anion, which inactivates catalase enzyme, with subsequent enhancement of $\mathrm{H}_{2} \mathrm{O}_{2}$ production and lipid peroxidation.

The present data revealed that the altered balance of antioxidant enzymes in the testes of penconazole-treated rats might be responsible for inadequacy of the antioxidant defense in combating ROS-mediated damage. Superoxide dismutase and catalase play an important role in maintaining physiological levels of oxygen and peroxy radicals by hastening the dismutation of oxygen radicals and eliminating organic peroxides and hydroperoxides. 
A significant reduction in LPO level and SOD activity was recorded in the testes of sesame seed oil-administered rats, compared to the control groups. Sesame seed oil has a good stability against autooxidation, which is attributed to its lignans and tocopherols content. The most important tocopherol in sesame seed oil is $\mathrm{Y}^{-}$ tocopherol. It trapped peroxynitrite formed by the reaction of NO and active oxygen so that it inhibited lipid peroxidative damage (Wan et al., 2015).

Co-administration of penconazole-treated rats with sesame seed oil reduced LPO level and normalized testicular CAT activity, compared with penconazole-treated animals. This is likely due to antioxidative properties of sesame which has various bioactive compounds including phytosterols, tocopherols and lignans such as sesamin, sesamolin, sesaminol and a small amount of sesamol which are known to play an important role in providing stability against oxidation of oil and contribute to antioxidative activity (Soliman et al., 2015). In addition, reduction in LPO level might be partly due to the direct scavenging of ROS by sesame seed (Kamboj et al, 2006).

The present study revealed that penconazole residues in testicular tissues of male rats after subchronic exposure ( 90 days) were below the limit of determination (LOD, $0.001 \mathrm{ppm}$ by gas chromatography) and there is no evidence for its accumulation. These results agree with that of Abd-Alrahman et al. (2014) who reported that oral administration of adult male Wistar rats with difenoconazole (10 $\mathrm{mg} / \mathrm{kg} \mathrm{b.} \mathrm{w.)} \mathrm{for} 28$ consecutive days induced oxidative stress, however difenoconazole residues were below the limit of determination in both liver and kidney as measured by high performance liquid chromatography (HPLC) analysis.

In conclusion, the results of current study demonstrated that penconazole has the ability to induced oxidative damage in testicular tissue of adult male rats, as evidenced by the enhancement of lipid peroxidation and suppression of antioxidant enzymes. Moreover, co-administration of sesame seed oil along with penconazole intoxication protected the testes from the induced toxicity by lowering testicular lipid peroxidation level and inducing antioxidant enzymes activity. Further studies are needed to complement the findings of the present study to illustrate the toxicity mechanisms of triazole and ameliorative effect of sesame seed oil against testicular dysfunction.

Acknowledgements: The authors would like appreciate the facilities offered by the Central Agricultural Pesticide Laboratory (CAPL), Agricultural Research Center (ARC), Dokki, Giza. 
Table 1. Effect of penconazole and sesame seed oil alone or co-administered with penconazole on testicular malondialdehyde (MDA) and glutathione levels (GSH) as well as catalase (CAT) and superoxide dismutase (SOD) activities in male rats.

\begin{tabular}{|c|c|c|c|c|}
\hline \multirow[b]{2}{*}{ Groups } & MDA & GSH & CAT & SOD \\
\hline & (n mol/g tissue) & $\begin{array}{c}\text { ( } \mu \mathrm{mol} / \mathrm{g} \\
\text { tissue) }\end{array}$ & $\begin{array}{c}\text { (U/mg } \\
\text { protein) }\end{array}$ & (U/mg protein) \\
\hline \multicolumn{5}{|l|}{ Control } \\
\hline Mean \pm SD & $42.05 \pm 3.56$ & $3.73 \pm 0.31$ & $10.82 \pm 2.00$ & $6.59 \pm 0.60$ \\
\hline Range & $(37.95-46.16)$ & $(3.33-4.14)$ & $(8.28-13.57)$ & $(5.82-7.32)$ \\
\hline \multicolumn{5}{|l|}{ Ses } \\
\hline Mean \pm SD & $31.65 \pm 1.40^{\text {acdf }}$ & $3.88 \pm 0.36$ & $11.19 \pm 1.43^{\mathrm{cd}}$ & $5.40 \pm 0.27^{\text {acdef }}$ \\
\hline Range & (29.74-33.64) & $(3.53-4.31)$ & $(9.80-13.11)$ & $(5.13-5.70)$ \\
\hline${ }^{*}$ Change $\%$ & -24.73 & 4.02 & 3.42 & -18.06 \\
\hline \multicolumn{5}{|l|}{ LD PEN } \\
\hline Mean \pm SD & $47.46 \pm 4.75^{\text {bde }}$ & $3.66 \pm 0.25$ & $5.25 \pm 0.30^{\text {abef }}$ & $4.79 \pm 0.20^{\mathrm{abdf}}$ \\
\hline Range & $(42.00-54.36)$ & $(3.31-3.95)$ & $(4.90-5.61)$ & $(4.46-4.98)$ \\
\hline${ }^{*}$ Change $\%$ & 12.87 & -1.88 & -51.48 & -27.31 \\
\hline \multicolumn{5}{|l|}{ HD PEN } \\
\hline Mean \pm SD & $70.73 \pm 5.52^{\text {abcef }}$ & $3.80 \pm 0.13$ & $5.45 \pm 0.36^{\text {abef }}$ & $5.89 \pm 0.11^{\text {abcef }}$ \\
\hline Range & $(63.08-76.92)$ & $(3.60-3.94)$ & $(5.18-5.86)$ & $(5.76-6.00)$ \\
\hline${ }^{*}$ Change $\%$ & 68.20 & 1.88 & -49.63 & -10.62 \\
\hline \multicolumn{5}{|l|}{ Ses+LD PEN } \\
\hline Mean \pm SD & $31.72 \pm 5.05^{\text {acdf }}$ & $3.56 \pm 0.37$ & $11.21 \pm 0.15^{\mathrm{cd}}$ & $4.76 \pm 0.40^{\text {abdf }}$ \\
\hline Range & $(25.13-37.95)$ & $(3.18-4.13)$ & $(11.0211 .37)$ & $(4.24-5.18)$ \\
\hline *Change\% & -24.57 & -4.56 & 3.60 & -27.77 \\
\hline$* *$ Change $\%$ & -33.16 & -2.73 & 113.52 & -0.63 \\
\hline \multicolumn{5}{|l|}{ Ses+HD PEN } \\
\hline Mean \pm SD & $45.76 \pm 3.74^{\text {bde }}$ & $3.90 \pm 0.40$ & $10.74 \pm 1.83^{\mathrm{cd}}$ & $2.95 \pm 0.11^{\text {abcde }}$ \\
\hline Range & $(39.49-48.31)$ & $(3.30-4.44)$ & $(8.64-12.76)$ & $(2.80-3.08)$ \\
\hline${ }^{*}$ Change $\%$ & 8.82 & 4.56 & -0.74 & -55.24 \\
\hline$* * *$ Change $\%$ & -35.30 & 2.63 & 97.06 & -49.92 \\
\hline F-ratio & 58.14 & NS & 26.56 & 70.24 \\
\hline
\end{tabular}

-Results are mean $\pm S D$. The F-ratio is significant at $p<0.05$.

-The letters $a, b, c, d, e$, and $f$ denote significant change versus Control, Ses, LD PEN, HD PEN,

Ses+ LD PEN and Ses+ HD PEN groups, respectively.

$\left(^{*}\right)$ percentage change versus Control group.

$(* *)$ percentage change versus LD PEN group.

$(* * *)$ percentage change versus HD PEN group. 


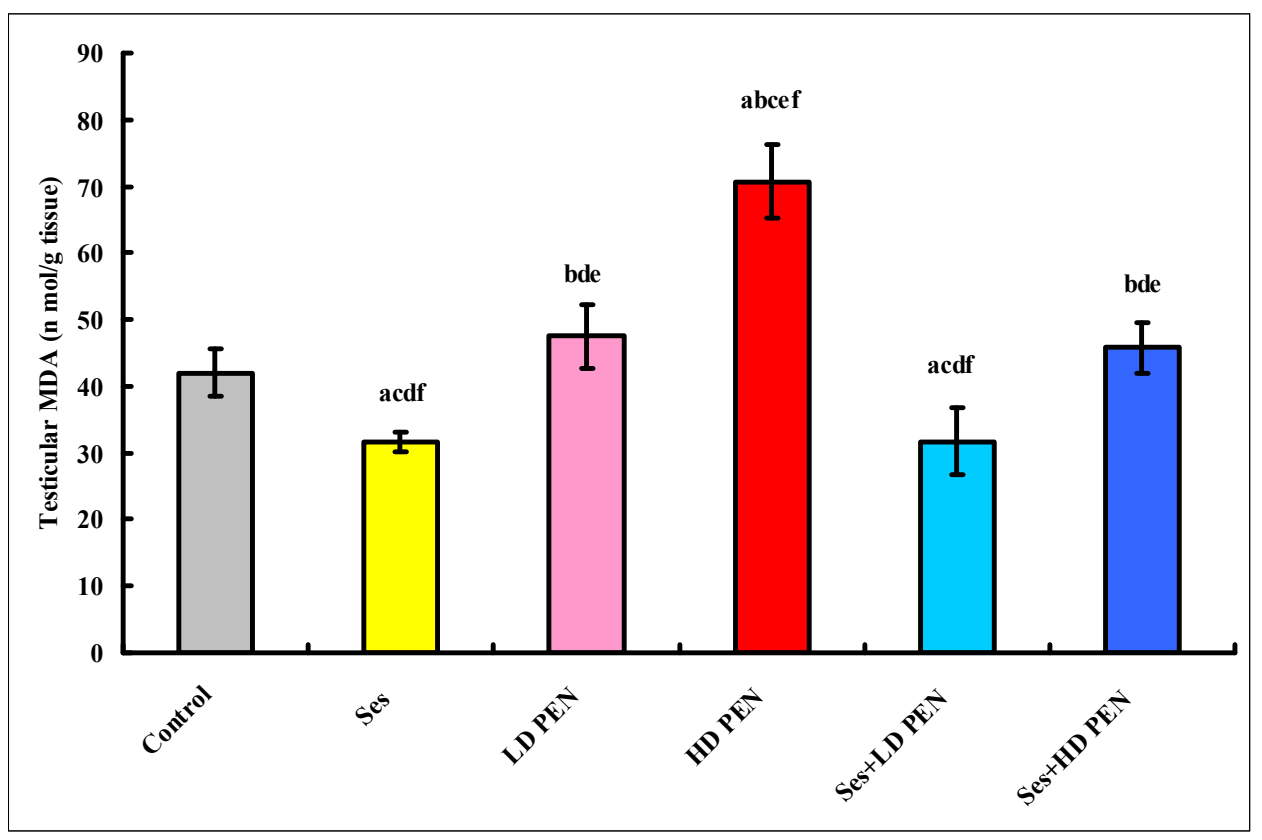

Fig. 1. Statistical significance of testicular malondialdehyde (MDA) level in different groups.

-Values are expressed as mean \pm SD.

-The letters $a, b, c, d$, e, and f denote significant change versus Control, Ses, LD

PEN, HD PEN, Ses+ LD PEN and Ses+HD PEN groups, respectively.

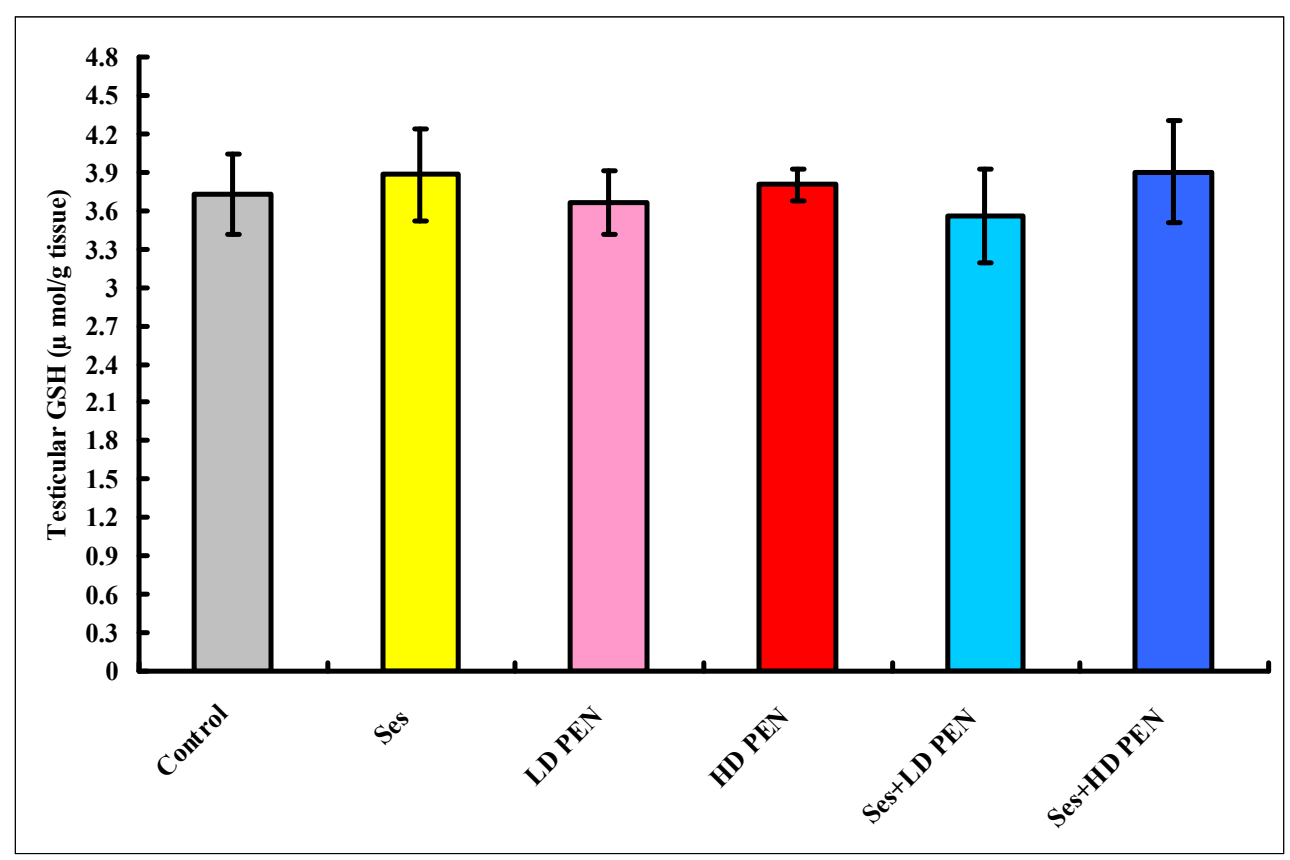

Fig. 2. Statistical significance of testicular glutathione (GSH) level in different groups.

-Values are expressed as mean \pm SD. 


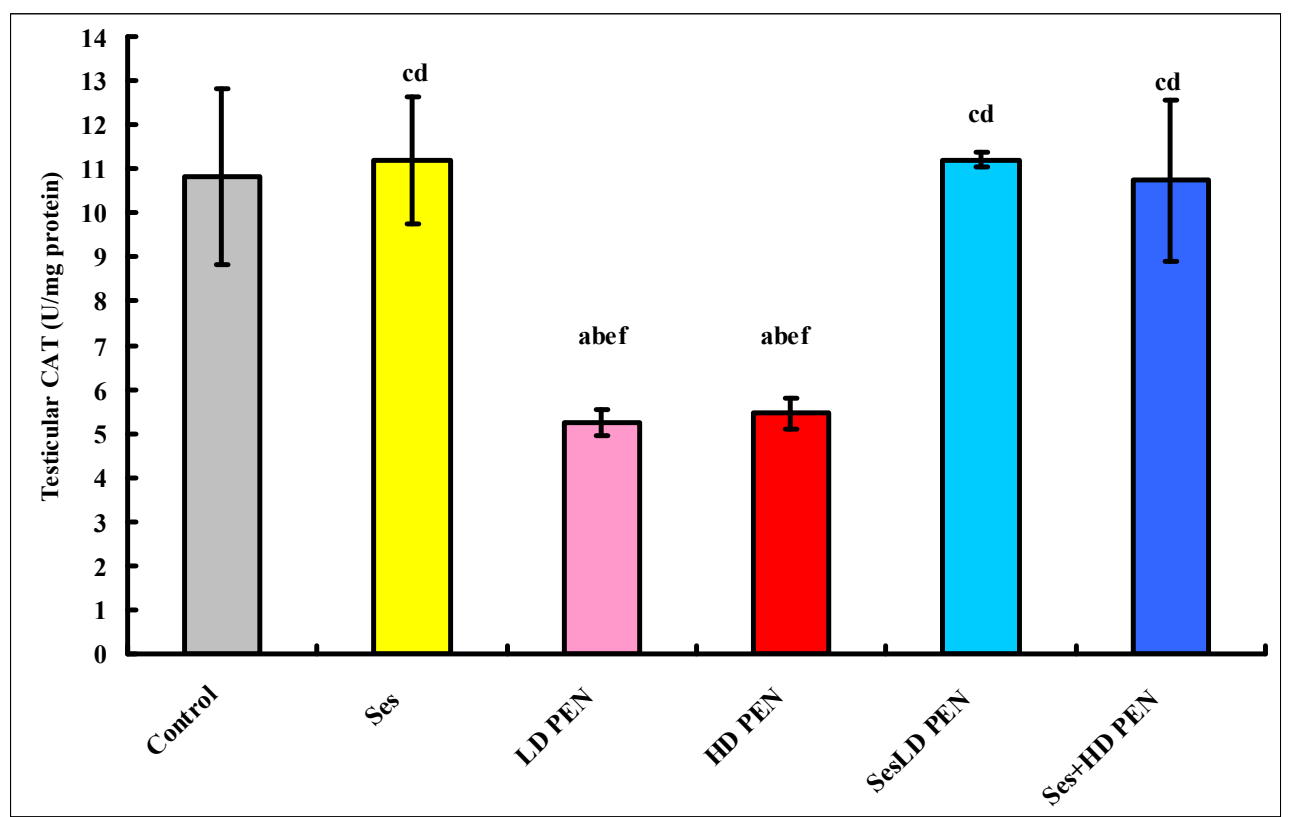

Fig. 3. Statistical significance of testicular catalase (CAT) activity in different groups.

-Values are expressed as mean \pm SD.

-The letters $a, b, c, d, e$, and $f$ denote significant change versus Control, Ses, LD

PEN, HD PEN, Ses+ LD PEN and Ses+ HD PEN groups, respectively.

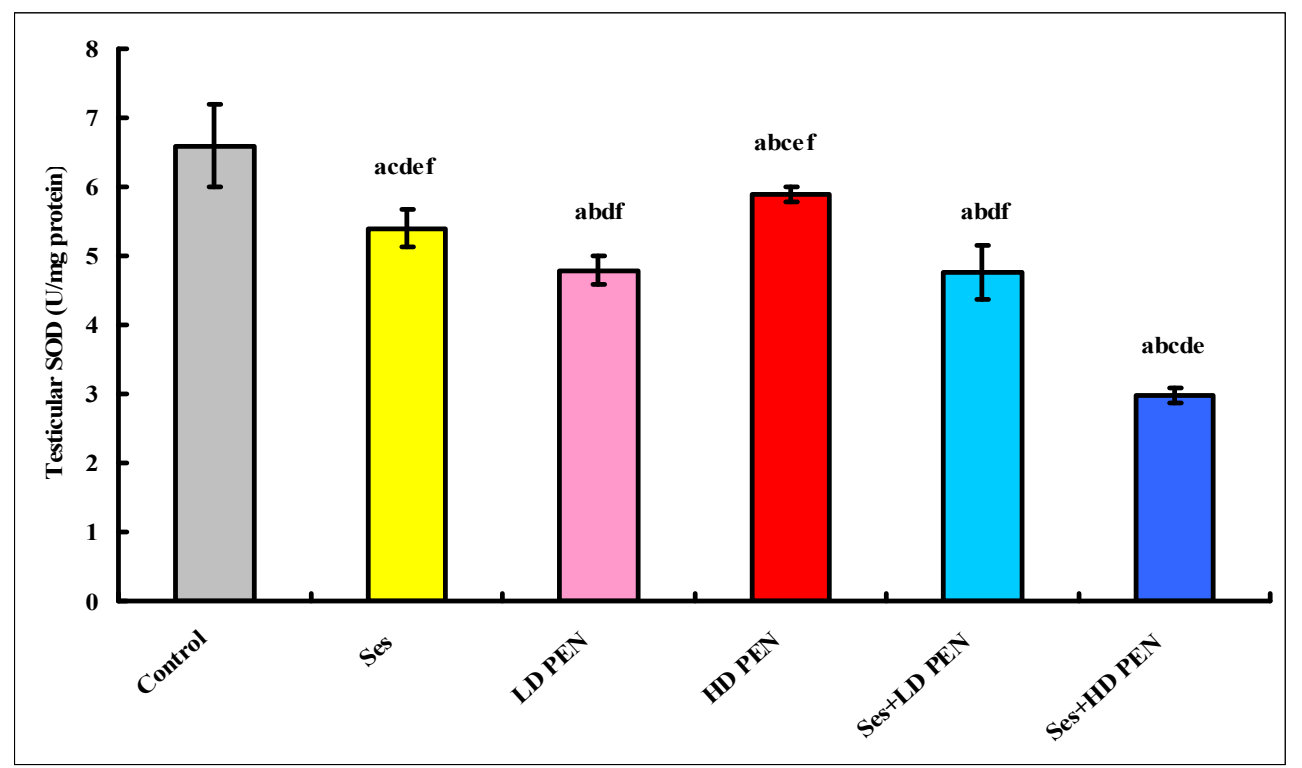

Fig. 4. Statistical significance of testicular superoxide dismutase (SOD) activity in different groups.

-Values are expressed as mean \pm SD.

-The letters a, b, c, d, e, and f denote significant change versus Control, Ses, LD

PEN, HD PEN, Ses+ LD PEN and Ses+ HD PEN groups, respectively. 


\section{REFERENCES}

1. Abd-Alrahman, S. H.; Ellhalwagy, M. E. A.; Kotb, G. A.; Farid, H.; Farag, A. A. G.; Draz, H. M.; Isa, A. M. and Sabico, S. 2014. Exposure to difenoconazole, diclofopmethyl alone and combination alters oxidative stress and biochemical parameters in albino rats. Int J Clin Exp Med 7(10): 3637-3646.

2. Aiche, M. A.; Mallem, L.; Yahia, E. and Boulakoud, M. S. 2015. Toxicity of subchronic doses of propiconazole, propineb and their mixture on reproductive parameters in male rats. Advan Environ Biol 9(3): 885-891.

3. Bradford, M. M. 1976. A rapid and sensitive method for the quantitation of microgram quantities of protein utilizing the principle of protein-dye binding. Analyt Biochem 72: 248-254.

4. Cabizza, M.; Dedola, F. and Satta, M. 2012. Residues behavior of some fungicides applied on two greenhouse tomato varieties different in shape and weight. $J$ Environ Sci Health 47: 379-384.

5. Chaâbane, M.; Ghorbel, L.; Elwej, A.; Mnif, H.; Boudawara, T.; Chaâbane, S. E.; Zeghal, N. and Soudani, N. (2017 $)$ : Penconazole alters redox status, cholinergic function, and membrane- bound ATPases in the cerebrum and cerebellum of adult rats. Hum Exper Toxico/ 36(8) 854-866.

6. Chaâbane, M.; Koubaac, M.; Soudania, N.; Elweja, A.; Gratid, M.; Jamoussid, K.; Boudawarae, T.; Chaabouni, S. E. and Zeghala, N. $\left(2017^{\mathrm{b}}\right)$ : Nitraria retusa fruit prevents penconazole-induced kidney injury in adult rats through modulation of oxidative stress and histopathological changes. pharma Bio 155(1): 1061-1073.

7. Chaâbane, M.; Tir, M.; Hamdi, S.; Boudawara, O.; Jamoussi, K.; Boudawara, T.; Ghorbel, R. E.; Zeghal, N. and Soudani, N. 2016. Improvement of heart redox states contributes to the beneficial effects of selenium against penconazoleinduced cardiotoxicity in adult rats. Biol Trace Elem Res 169: 261-270.

8. Chaâbane, M.; Soudani, N.; Benjeddou, K.; Turkic, M.; Maknic, F. A.; Boudawarad, T.; Zeghalb, N. and Ghorbela, R. E. 2015. The protective potential of Nitraria retusa on penconazole- induced hepatic injury in adult rats. Toxicol Environ Chem 97: 1253-1264.

9. Cohen, G.; Dembiec, D. and Marcus, J. 1970. Measurment of catalase activity in tissue extract. Anal Biochem 34: 30-38.

10. El-Demerdash, F. M.; Yousef, M. I.; Kedwany, F. S. and Baghdadi, H. H. 2004. Role of a-tocopherol and $\beta$-carotene in ameliorating the fenvalerate-induced changes in oxidative stress, hemato-biochemical parameters, and semen quality of male rats. J Environ Sci Health 39(3): 443-459. 
11. El-Kashoury, A. A.; Salama, A. F.; Selim, A. I. and Mohamed, R. A.; 2010. Chronic expossure of dicofol promotes reproductive Toxicity in mal rats. Life Sci 7 (3): 519.

12. El-Kashoury, A. A. and Tag El-Din, H. A. 2010. Chlorpyrifos (from different sources): Effect on testicular biochemistry of male albino rats. J Am Sci 6(7): 252261.Ellman G L. 1959. Tissue sulfhydryl groups. Arch Biochem Biophys 82: 70-77.

13. Hsu, D. Z.; Liu, C. T.; Li, Y. H.; Chu, P.Y. and Liu, M. Y. 2010. Protective effect of Daily sesame oil supplement on gentamicin-induced renal injury in rats. Shock 33(1): 88-92.

14. Isha, D. and Milind, P. 2012. Eat til and protect dil. Int Res J Pharm 3(11): 54-57.

15. Kamboj, A.; Kiran, R. and Sandhir, R. 2006. Carbofuran-induced neurochemical and neurobehavioral alterations in rats: attenuation by $\mathrm{N}$-acetylcysteine. Exp Brain Res 170: 567-575.

16. Latchoumycandane, C. and Mathur, P. P. 2002. Effect of methoxychlor on antioxidant system in mitochondrial and microsome-rich fractions of rats testis. Toxicology 176: 67-75.

17. Marklund, S. and Marklund, G. 1974. Involvement of the superoxide anion radical in the autoxidation of pyrogallol and a convenient assay for superoxide dismutase. Eur J Biochem 47: 469-474.

18. Marzook, E. A.; Abd El Moneim, A. E. and Elhadary, A. A. 2014. Protective role of sesame oil against mobile base station-induced oxidative stress. J Rad Res Appl Sci 7: 1-6.

19. Mnif, W.; Hassine, A. I. H.; Bouaziz, A.; Bartegi, A.; Thomas, O. and Roig, B. 2011. Effect of endocrine disruptor pesticides: a review. Int J Environ Res Public Health 8(6): 2265-2303.

20. Najafi, G.; Razi, M.; Hoshyar, A.; Mohamadlou, S. and Feyzi, S. 2010. The effect of chronic exposure with imidacloprid insecticide on fertility in mature male rats. Int J Fertil Steril 4(1): 9-16.

21. Pang, G. F.; Cao, Y. Z.; Zhang, J. J.; Fan, C. L.; Liu, Y.M.; Li, X. M.; Jia, G. Q.; Li, Z.Y.; Shi, Y.Q.; Wu, Y. P. and Guo, T. T. 2006. Validation study on 660 pesticide residues in animal tissue by gel permeation chromatography cleanup/gas chromatography-mass spectrometry and liquid chromatography-tandem mass spectrometry. J Chromatog A 1125(1): 1-30.

22. Silberstein T.; Har-Vardi I.; Harlev A.; Friger M.; Hamou B.; Barac T.; Levitas E. and Saphier, O. 2016. Antioxidants and polyphenols: concentrations and relation to male infertility and treatment success. Oxid Med Cell Longev 2016: 1-5. 
23. Singh, N. 2005. Mobility of four triazole fungicides in two Indian soils. Pest Manag Sci 61: 191-196.

24. Soliman, M. M.; Attia, H. F. and El-Ella, G. A. 2015. Genetic and histopathological alterations induced by cypermethrin in rat kidney and liver: protection by sesame oil. Int J Immunopath Ph 28(1): 9-22.

25. Tuener, J. R. and Thayer, J. F. 2001. Introduction to analysis of variance: Design analysis, and interpretation. Sage Publication, Thousand Oaks, CA.

26. Wan, Y.; Li, H.; Fu, G.; Chen, X.; Chen, F. and Xie, M. 2015. The relation of antioxidant components and antioxidant activity of sesame seed oil. J SCi Food Agric 95(13): 2571-8.

27. Weil, C. S. 1952. Tables for convenient calculation of medium effective $\left(L_{50}\right.$ or $\mathrm{EC}_{50}$ ) and instruction in their use. Biometrics 8: 249-263.

28. Wills, E. D. 1966. Mechanisms of lipid peroxide formation in animal tissues. Biochem J 99: 667-676. 


\section{الاور الوقائى لزيت بذرة السمسم ضد الأجهاد التأكسدى \\ فى خصيات ذكور الجرذان المعاملة \\ بالبينكونازول}

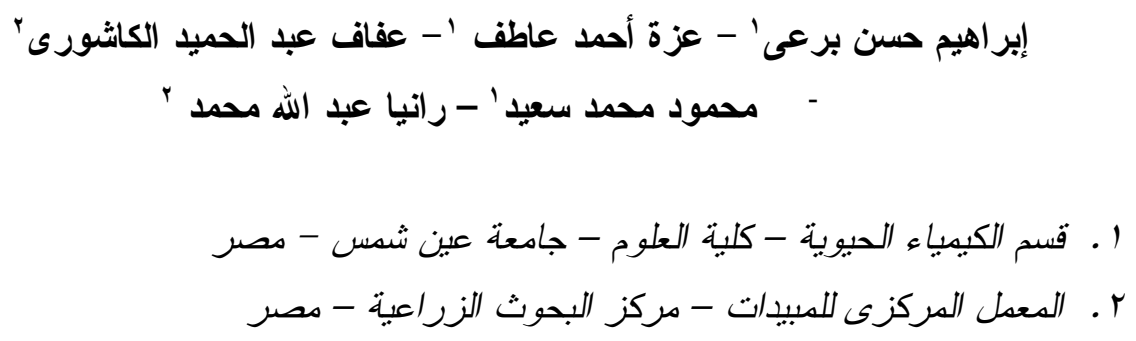

أجرى هذا البحث لتوضيح دور زيت بذرة السمس فى حماية خصيات ذكور الجرذان البيضاء

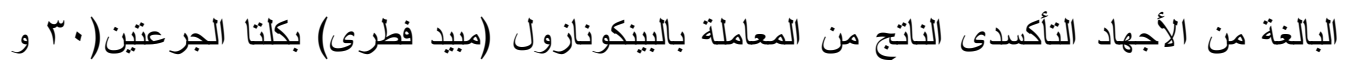

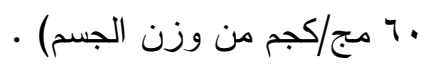

أجريت هذه الاراسة على ، ج جرذ و تم تقسيمهم عشوائيا إلى ست مجموعات متجانسة كالتالى:

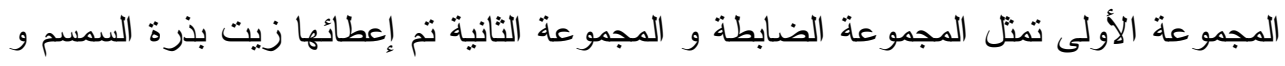

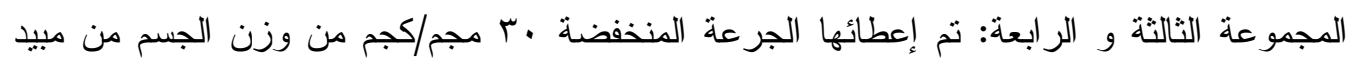

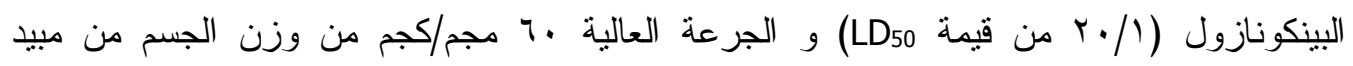

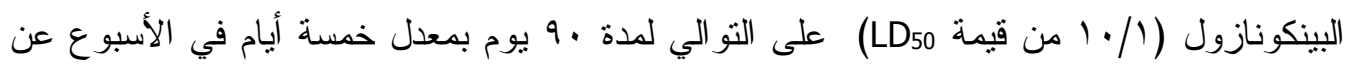

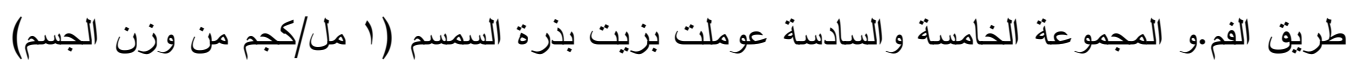

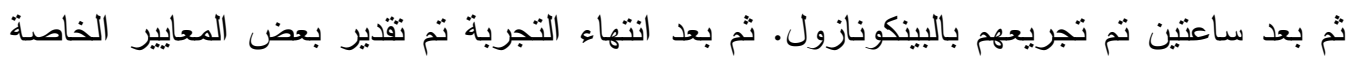

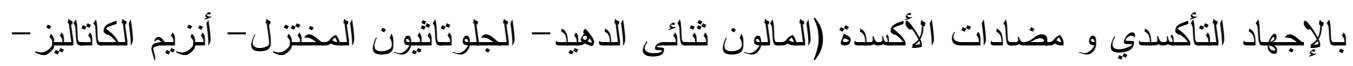

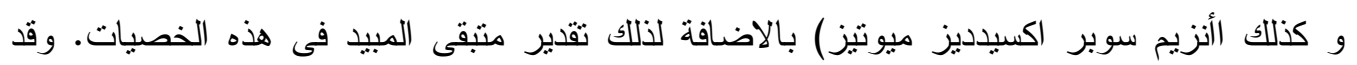

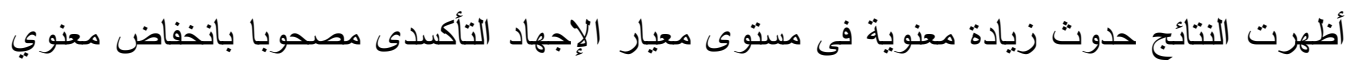

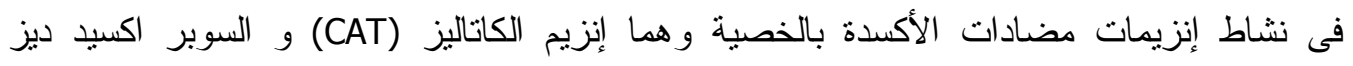

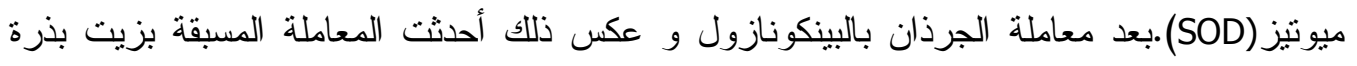

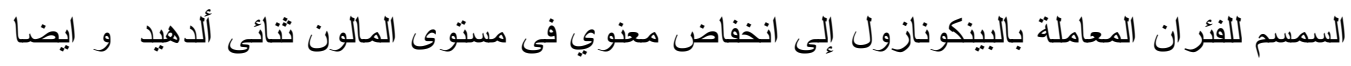

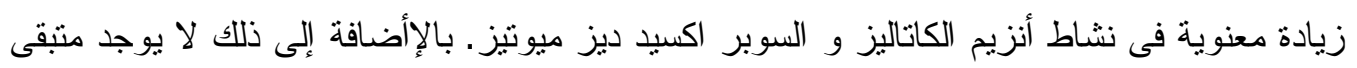

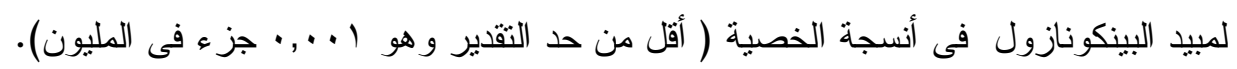
الخلاصة: وقد أنشارت النتائج إلى أن معاملة ذكور الجرذان البيضاء بزيت بذرة البناء السمسم قبل المعاملة بمبيد البينكونازول يحمى الخصية من الإجهاد التأكسدي الناتج عن التعرض للمبيد. 